\title{
Response of a Sweet Corn $x$ Tropical Maize Composite to Mass Selection for Temperate-zone Adaptation
}

\author{
David B. Rubino ${ }^{1}$ and David W. Davis ${ }^{2}$ \\ Department of Horticultural Science and Landscape Architecture, University of Minnesota, St. \\ Paul, MN 55108
}

Additional index words. Zea mays, exotic germplasm, recurrent selection, combining ability, genotypic variance, heterosis

\begin{abstract}
This study was conducted to investigate the effects of mild mass selection for adaptation on the performance, genotypic variance, combining ability, $S_{1}$ family-testcross correlation, and midparent heterosis of $S_{1}$ families derived from a sweet corn $(\mathrm{su}) \times$ tropical maize (Zea mays L.) composite (Composite 1R). Four cycles of random mating followed by 10 cycles of $10 \%$ stratified mass selection were conducted for earliness, plant and ear type, and freedom from pests. Selection significantly $(P<0.01)$ decreased plant height, ear height, percentage barrenness, and ear length, and significantly (P < 0.01) increased stalk breakage, earliness (Celsius heat units to $50 \%$ anthesis and silking), and kernel row number of both $S_{1}$ families and their testcrosses. Juvenile plant height at 45 days after planting increased in testcrosses only. Percentage tip blanking and pericarp thickness did not change. For most traits, the greatest response occurred during the first five of 10 selection cycles. Cycle 10 testcrosses performed at least as well as elite check testcrosses for eight of $\mathbf{1 0}$ traits. The tropical parents improved combining ability for increased juvenile plant height and kernel row number, and decreased percentage of stalk breakage. As a result of selection, genotypic variance among $S_{1}$ families decreased by $>40 \%$ for heat units to $50 \%$ anthesis and silking, ear height, and percentage of barrenness, although for all traits measured, significant genotypic variation persisted following 10 cycles of mass selection for adaptation. $S_{1}$-testcross correlations and percentage midparent heterosis tended to be consistent across selection cycles. Five cycles of mild stratified mass selection increased the adaptation of a temperate sweet corn $x$ tropical maize composite to the temperate zone of the United States while maintaining significant genotypic variation.
\end{abstract}

Until recently, sweet corn breeders relied chiefly on adapted sugary $(\mathrm{su})$ germplasm as source material for genetic improvement. The recovery of kernel quality and the many stringent raw product specifications following hybridization with nonsweet maize (Kaukis and Davis, 1986; Singleton, 1948) were thought to be difficult. Many sources of tropical germplasm are sensitive to photoperiod, temperature, and other environmental factors and are difficult to grow in temperate zones (Kannenberg, 1981; Lonnquist, 1974). Furthermore, the presence of useful genetic diversity in elite, adapted breeding lines, cited as a reason for the minimal amounts of tropical germplasm in U.S. field corn hybrids (Duvick, 1984), also applies to sweet corn.

Most sweet corn hybrids released before 1971 can be traced to a few open-pollinated cultivars of similar origin (Galinat, 1971). Since Moll et al. (1965) showed that heterosis increased in maize with increased genetic divergence within a restricted range, incorporation of unrelated germplasm into sweet corn populations should increase heterosis. Exotic germplasm has been shown to increase genetic variability and heterosis in maize (Goodman, 1965; Moll et al., 1965) and likely will be useful in long-term breeding programs (Hallauer and Miranda, 1981).

Tropical maize has been used as a pest resistance source in temperate sweet corn breeding (Davis and Grier, 1978; Marston and Mahoney, 1932). However, the potential of tropical germ-

Received for publication 10 Oct. 1989. Univ. of Minnesota Journal Series no. 17217. Consultation from Elmer Johnson of Escagenetics Corp., San Carlos, Calif. (formerly of CIMMYT) is gratefully acknowledged. The cost of publishing this paper was defrayed in part by the payment of page charges. Under postal regulations, this paper therefore must be hereby marked advertisement solely to indicate this fact.

'Graduate Research Assistant. Currently Research Geneticist, USDA-ARS, Florist and Nursery Crops Laboratory, Beltsville, MD 20705.

${ }^{2}$ Professor. plasm for improving combining ability for yield, vigor, agronomic performance, and quality of temperate-adapted sweet corn has not been adequately investigated.

Crossing exotic maize germplasm with adapted germplasm is a common method of raising the level of performance before recurrent selection. Several generations of random mating, with or without mild recurrent selection for adaptation, is recommended (Hallauer, 1978; Lonnquist, 1974) to reduce linkage disequilibrium and to increase the frequency of favorable alleles (Compton et al., 1979).

Mild mass selection is used often for adapted $\mathrm{x}$ exotic crosses because it is a simple procedure and a large effective population size can be maintained easily. Mass selection is most useful in modifying highly heritable traits, but it can also be effective for traits such as yield (Hallauer and Miranda, 1981), especially during early generations in variable populations. Temperate field corn $\mathrm{x}$ exotic populations have been mass selected for adaptation to northern latitudes (Compton et al., 1979; Troyer and Brown, 1972). Troyer and Larkins (1985) found that mass selection for earlier maturity in an adapted $\mathrm{x}$ exotic population was effective and resulted in correlated responses of decreased plant height and silk delay but increased yield and percentage of stalk breakage.

Intense selection for simply inherited traits during the early generations following a cross may result in a loss of the exotic component, thereby reducing the frequency of effective recombination (Hanson, 1959). This effect can be reduced somewhat by random mating for several generations before selection (Holley and Goodman, 1988), although there is little control over natural selection during this time. Natural selection may be particularly intense when photoperiod-sensitive tropical germplasm is crossed with adapted germplasm and random mated under the long days of northern latitudes. However, plants exhibiting characteristics of the tropical parents may be selected during the 
early generations of random mating to help maintain the tropical component (Troyer and Brown, 1972).

Although a genetically diverse array of tropical maize germplasm exists, its very limited use in sweet corn breeding may be due to uncertainty among breeders as to the most" efficient method of selection for adaptation to temperate environments. Long-term breeding strategies for the use of tropical maize germplasm are not well-developed (Compton et al., 1979; Holley and Goodman, 1988), particularly for sweet corn. Various selection strategies need to be examined critically for efficacy in adapting temperate $\times$ tropical populations to temperate en vironments while maintaining useful genetic variation and heterosis.

The present study was conducted to determine the effects of mild stratified mass selection for temperate zone adaptation in a temperate sweet. corn $\mathrm{x}$ tropical maize composite. The effects of selection on the performance of $S_{1}$ families, specific combining ability, genotypic variance, $\mathrm{S}_{1}$ family-testcross correlation, and midparent heterosis were investigated.

\section{Materials and Methods}

A composite population (1R) derived from intermating 11 U.S. temperate-adapted sweet corn $(s u)$ inbreds with 17 cultigens and land races from Peru, Mexico, and Cuba was used for this study (Table 1). Nine of the 11 U.S. sweet corn inbreds were developed at state agricultural experiment stations. They are generally recognized for their excellence in combining ability for yield, but they vary widely for earliness, quality, and type. Two (G.G.22 and G.G.62) were proprietary inbreds provided by The Pillsbury Company. The 17 tropical parents were chosen because of their use as fresh (green) corn for human consumption.

Following self-pollination of the $187 \mathrm{~F}_{1}$ plants and the bulking of equal amounts of $\mathrm{F}_{2}$ seed from each cross, a composite population was developed by open-pollination in an isolated plot and by enforced hybridization in another plot. In both plots, three plantings were made each season to reduce positive assortative mating. In the isolated plot, an equal amount of seed for the next generation was taken from each plant. In

Table 1. Parents of sweet corn Composite 1R.

\begin{tabular}{ll}
\hline \hline Tropical parents and source & U.S. $(s u)$ inbred parents \\
\hline Peru & I453 \\
Paro & I5125 \\
Chullpi & P39 \\
Huayleno & P51 \\
Piscorunto & G.G.22 \\
Comp. Dulce & G.G.62 \\
Chapareno & C6 \\
Mexico & Ill 18b \\
Comp. Gto. Gpo. 13 \#1382 & Ill 27a \\
Comp. Gto. Gpo. 14 \#1383 & Ill 101t \\
Comp. Gro. Gpo. 15 \#1396 & \\
Comp. Pue. Gpo. 12 \#5081 & \\
Mich. 4 \#2134 & \\
Maiz Dulce Gto. 93A \#1354 & \\
Mich. 15 \#2124 & \\
Dulcilo de Sonora 57 \#1568 & \\
Jalisco 188 \#1453 Tep. 60-61 & \\
Gto. 98 \#1352 Tep. 60-61 & \\
P.M.S. 265y & \\
\hline
\end{tabular}

${ }^{2}$ We thank The Pillsbury Co., Le Sueur, Minn., for permission to use inbreds G.G.22 and G.G.62.

y.M.S. 265 contains Cuban germplasm. the enforced hybridization plot, hand pollinations were made between early flowering plants in the two late plantings and late plants in the early planting, with each female contributing equally to the next generation. Seed from the two plots was bulked in proportion to the number of plants that contributed seed. Each plot contained $\approx 7,000$ plants. Plots were overplanted and thinned to obtain a uniform stand without regard to seedling vigor.

Beginning in 1973, mild stratified mass selection was performed annually with one of 10 plants selected from a population of $=14,000$. Selection was based on a visual appraisal of earliness, plant type, ear type, and freedom from pests. Planttype rating was based on early vigor at the time of thinning and on shorter plant and ear height and increased lodging resistance at the time of seed harvest before frost.

Ear-type rating was based on an array of attributes important to the U.S. fresh-market and processing trades (Kaukis and Davis, 1986). Selection was practiced for long ears, high kernel row number, light silk and cob color, good tip fill, cylindrical ear shape, complete husk cover, bright yellow kernel color, and sugary endosperm type.

Plants with severe symptoms of common smut [Ustilago maydis (DC.) Cola.], common corn rust (Puccinia sorghi Schw.), or damage from the European corn borer (Ostrinia nubilalis Hubner) were not selected. However, plants were not subjected to artificial epidemics or infestations, and natural occurrences of diseases and insects tended to be low during the 10 cycles of mass selection. In addition, Davis et al. (1990) found that resistance to common leaf rust in Composite 1R eroded significantly during the 10 cycles of mass selection. Therefore, pest resistance was not evaluated in this study, since selection pressure was low.

In 1984, random plants from remnant seed of Composite $1 \mathrm{R}$ at cycle O (1972), cycle 5 (1977), and cycle 10 (1982) were self-pollinated to produce $180 \mathrm{~S}_{1}$ families for each cycle. In 1985, 40 random families per cycle were testcrossed, using a mixture of pollen from three to five $S_{1}$ plants from each family, with $s u$ inbreds I453 and I5125B, the parents of the single cross hybrid 'Iochief B'. The sugary U.S. inbred parents of Composite $1 \mathrm{R}$ (Table 1) were also crossed with I453 and I5125B to produce 20 hybrid controls (excluding I453 $\times$ I453 and I5125B $\times$ I5125).

The experiments reported herein were conducted in 1985 and 1986 on Waukegan silty clay loam (Typic Hapludoll) at St. Paul, Minn., and on irrigated loamy sand (Hubbard, Udorthentic Haploboroll) at Becker, Minn. Standard cultural practices were used at both locations. Single-row plots $3 \mathrm{~m}$ long were overplanted and thinned to $0.3 \mathrm{~m}$ spacing. Row spacing was $0.9 \mathrm{~m}$ at St. Paul and $0.8 \mathrm{~m}$ at Becker, resulting in plant densities of 37,037 and 41,667 plants/ha, respectively. Fields in both years and at both locations were bordered on each side with either cycle 10 of Composite $1 \mathrm{R}$ or with a commercial sweet corn hybrid.

In 1985 , the $180 \mathrm{~S}_{1}$ families from each of cycles 0,5 , and 10 were planted as a split plot in a randomized complete-block design with cyles as whole plots and $S_{1}$ families as subplots with two blocks per location. Only cycles 0 and 10 were planted at Becker. In 1986, forty random $\mathrm{S}_{1}$ families from each cycle, their testcrosses with I453 and I5125B, and the 20 control testcrosses were planted as a split plot in a randomized completeblock design with testers as whole plots and $\mathrm{S}_{1}$ families as subplots with two blocks per location.

Although mass selection in Composite 1R had been based 
primarily on the subjective evaluation of earliness, plant type, and ear type, data in both 1985 and 1986 were obtained by measuring components of these traits. Celsius heat units (maximum $30 \mathrm{C}$, minimum 10C) to $50 \%$ anthesis and $50 \%$ silking were recorded at 2-day intervals to estimate earliness. To evaluate ear type, the primary ears were harvested 60 to 81 days after silking and ear length and kernel row number recorded. Tip blanking was calculated as the percentage of unfilled tip to total ear length. In 1986, plant type was evaluated by measuring juvenile plant height (45 days after planting) and plant and ear height (following anthesis) from the ground to the collar of the most recently expanded leaf, to.. the first tassel branch, and to the node subtending the primary ear, respectively. In addition, the percentage of barren plants $(<25 \%$ ear fill $)$ and the percentage of stalks broken below the ear 160 days after planting were recorded.

-Data were collected on individual competitive (bordered) plants for all traits except 50\% anthesis and 50\% silking, for which data were collected on a whole-plot basis. Data were averaged to provide plot values before analysis of variance (ANOVA) combined over locations within a year.

Linear regressions via orthogonal polynomials were used to evaluate response to selection -with cycles considered a fixed effect and data for each tester $\left(\mathrm{S}_{1}\right.$ families, I453 and I5125B testcrosses) analyzed separately. An ANOVA with a randomeffects model was used to estimate genotypic variance among $\mathrm{S}_{1}$ families for each cycle.

To determine if selection for other traits resulted in changes in a kernel quality trait, thickness of pericarp (a maternal trait), an important component of kernel tenderness in sweet corn (Kramer et al., 1949), was measured for $S_{1}$ kernels from 100 $\mathrm{S}_{0}$ plants for each of cycles 0,5 , and 10 . The testcrosses were not evaluated for pericarp thickness. The centers of the abgerminal sides of three remnant, dry kernels from each family were sectioned with a clinical microtome and stained with crystal violet (Kaukis and Davis, 1986). Since no significant variation in sweet corn pericarp thickness among kernels within ears has been found for the pressure micrometer method of measurement (Ito and Brewbaker, 1981; “Tracy and Schmidt, 1987), only three kernels per family were sectioned. Three pericarp sections per kernel were measured with an eyepiece micrometer in a light microscope at $40 \times$ magnification.

\section{Results}

$S_{I}$ families. Ten cycles of stratified mass selection for earliness and plant and ear type resulted in significant $(P<0.01)$ changes in performance for all traits except juvenile plant height, ear length (in 1985), percentage tip blanking, and pericarp thickness (Table 2). On average, cycle $10 \mathrm{~S}_{1}$ families required up to $11.9 \%$ fewer heat units to anthesis and up to $16.2 \%$ fewer heat units to silking than cycle $\mathrm{O}$ families. Cycle 10 families also had an average of $20.8 \mathrm{~cm}$ shorter plants, $27.5 \mathrm{~cm}$ lower ears, $21.7 \%$ less barrenness, $14.1 \%$ more stalk breakage, $1 \mathrm{~cm}$ shorter ears, and 2.6 more kernel rows per ear than cycle 0 families.

A significant $(P<0.01)$ lack of fit to a linear model occurred for all traits that responded to selection, except ear length and percentage of stalk breakage (Table 2). In most cases, this lack was due to. a greater response to selection during the first than during the second five cycles of mass selection.

Genotypic variances among $\mathrm{S}_{1}$ families decreased by $>40 \%$ from cycle 0 through cycle 10 for heat units to $50 \%$ anthesis and silking, and for ear height and percentage barrenness (Table 3 ). However, after 10 cycles of mild mass selection for adaptation, significant (more than twice the standard error) genetic variation remained in cycle 10 for all traits evaluated.

$S_{1}$ families in testcrosses. As estimated by testcross performance, response to selection was significant $(P<0.01)$ for all traits except percentage tip blanking (Table 4). For most traits, linear regression coefficients (in absolute values) for I5125B testcrosses were larger (from $10.7 \%$ to $167 \%$ ) than for 1453 testcrosses. Significant deviations from linear were found for anthesis and silking, ear height, percentage barrenness, and kernel row number for both sets of testcrosses. For $S_{1}$ families, no response was found for juvenile plant height (Table 2), whereas a significant increase in combining ability with both testers was found (Table 4).

The average cycle 10 testcross performances for juvenile plant height, kernel row number, and percentage of stalk breakage (I5125B testcrosses) are $5.8 \%$ to $21 \%$ superior to the averages of the check testcrosses of the elite, adapted parents of Composite 1R (Table 4). Cycle 10 testcrosses did not differ significantly from the check testcrosses for heat units to $50 \%$ anthesis and silking, percentage barrenness, percentage stalk breakage (I453 testcrosses only), ear length, and percentage tip blanking (I453 testcrosses only). Plant and ear heights of the cycle 10

Table 2. Mean values ${ }^{2}$ of plant and ear characteristics in $\mathrm{S}_{1}$ families, linear regression coefficient (b), and lack of fit (LOF) to a linear model for three cycles of selection, tested in two locations in each of 2 years.

\begin{tabular}{|c|c|c|c|c|c|c|c|c|c|c|}
\hline \multirow[b]{3}{*}{ Characteristic } & \multicolumn{5}{|c|}{$1985^{y}$} & \multicolumn{5}{|c|}{1986} \\
\hline & \multicolumn{3}{|c|}{ Cycle } & \multirow[b]{2}{*}{$\mathrm{b}$} & \multirow[b]{2}{*}{ LOF } & \multicolumn{3}{|c|}{ Cycle } & \multirow[b]{2}{*}{$\mathrm{b}$} & \multirow[b]{2}{*}{ LOF } \\
\hline & $\mathrm{CO}$ & $\mathrm{C} 5$ & $\mathrm{C} 10$ & & & $\mathrm{CO}$ & $\mathrm{C5}$ & $\mathrm{C} 10$ & & \\
\hline Anthesis (heat units) & 720 & 706 & 657 & $-6.7^{* *}$ & $* *$ & 697 & 626 & 613 & $-8.3^{* *}$ & $* *$ \\
\hline Silking (heat units) & 813 & 785 & 708 & $-12.0^{* *}$ & ** & 809 & 698 & 678 & $-13.1^{* *}$ & $* *$ \\
\hline Juvenile plant ht $(\mathrm{cm})$ & -- & -- & $\ldots$ & --- & -- & 34.1 & 33.0 & 35.1 & $0.1^{\mathrm{NS}}$ & ** \\
\hline Plant ht (cm) & --- & --- & $-\cdots$ & $\ldots$ & $\ldots$ & 201 & 183 & 180 & $-2.1 * *$ & $* *$ \\
\hline Ear ht $(\mathrm{cm})$ & --- & -- & $\cdots$ & --- & -- & 102 & 74.2 & 74.7 & $-2.8^{* *}$ & $* *$ \\
\hline Barrenness $(\%)$ & --- & $\cdots$ & --- & $\ldots$ & -- & 44.6 & 24.8 & 22.9 & $-2.2 * *$ & $* *$ \\
\hline Stalk breakage $(\%)$ & -- & $-\cdots$ & --- & $\ldots$ & -- & 12.4 & 17.5 & 26.5 & $1.4^{* *}$ & NS \\
\hline Ear length $(\mathrm{cm})$ & 14.4 & 13.6 & 14.0 & $0.0^{\mathrm{NS}}$ & NS & 16.9 & 16.4 & 15.9 & $-0.1^{* *}$ & NS \\
\hline Tip blanking (\%) & 10.0 & 9.9 & 10.5 & $0.0^{\mathrm{NS}}$ & NS & 7.6 & 7.0 & 8.3 & $0.1^{\mathrm{NS}}$ & NS \\
\hline Row number & 13.8 & 16.0 & 16.2 & $0.2^{* *}$ & $* *$ & 13.8 & 16.2 & 16.6 & $0.3^{* *}$ & $* *$ \\
\hline Pericarp thickness $(\mu \mathrm{m})^{\mathrm{x}}$ & 81.0 & 75.8 & 81.9 & $0.4^{\mathrm{NS}}$ & $* *$ & $\cdots$ & --- &.- &.-- & $\cdots$ \\
\hline
\end{tabular}

${ }^{2}$ Means over $180 \mathrm{~S}_{1}$ families per cycle in 1985 and over $40 \mathrm{~S}_{1}$ families per cycle in 1986.

yCycle 5 means and regression coefficients were estimated only from the St. Paul location in 1985. ${ }^{x}$ Data were from $S_{0}$ plants.

NS,**Nonsignificant or significant at $P=0.01$, respectively. 
Table 3. Estimates of genotypic variances' among $S_{1}$ families combined over two locations in each of 2 years.

\begin{tabular}{lcccccc}
\hline \hline & \multicolumn{3}{c}{ Cycle-1985 test ${ }^{\mathrm{y}}$} & \multicolumn{4}{c}{ Cycle-1986 test } \\
\cline { 2 - 7 } Characteristic & C0 & C5 & C10 & C0 & C5 & C10 \\
\hline Anthesis & 2363 & 1181 & 933 & 4011 & 1306 & 1321 \\
Silking & 3427 & 3342 & 1758 & 7847 & 3227 & 4486 \\
Juvenile plant ht & --- & --- & --- & 10.4 & 18.0 & 17.1 \\
Plant ht & --- & --- & --- & 240 & 307 & 213 \\
Ear ht & -- & --- & -- & 348 & 178 & 184 \\
Barrenness & --- & --- & -- & 377 & 198 & 205 \\
Stalk breakage & -- & --- & -- & 118 & $31.6^{\text {Ns }}$ & 455 \\
Ear length & 1.9 & 2.4 & 1.8 & 3.7 & 2.4 & 3.2 \\
Tip blanking & 12.0 & 14.7 & 16.5 & 15.5 & 5.8 & 9.1 \\
Row number & 2.2 & 2.6 & 3.1 & 3.8 & 4.5 & 2.6 \\
Pericarp thickness & 745 & 594 & 844 & -- & -- & --- \\
\hline
\end{tabular}

${ }^{z}$ All variance estimates are greater than twice their standard errors, except those marked NS.

yCycle 5 results reflect only the St. Paul location in 1985.

${ }^{x}$ Data were from $S_{0}$ plants.

testcrosses, although up to $13.3 \mathrm{~cm}$ higher than the controls, were acceptable by industry standards.

$S_{I}$ family testcross relationship. The $\mathrm{S}_{1} \mathrm{vs}$. testcross correlation coefficients differed from $0(P<0.05)$ for all traits except percentage barrenness (Table 5). The relationships were similar for $S_{1}$ vs. I453 and $S_{1}$ vs. I5125B. For anthesis, silking, plant height (for $\mathrm{S}_{1} \mathrm{vs} . \mathrm{I} 5125 \mathrm{~B}$ ), ear height, and kernel row number, $25 \%$ or more of the variation in testcrosses could be associated with the $S_{1}$ families used in the crosses at all three selection levels. Correlation coefficients for barrenness, percentage stalk breakage, and percentage tip blanking were relatively low.

Midparent heterosis. Percentage midparent heterosis values for I5125B testcrosses were at least twice the magnitude of the values for I453 testcrosses for increased juvenile plant height and ear length and for decreased percentage tip blanking (Table 6). I453testcrosses exhibited more heterosis than I5125B testcrosses for higher ear height and kernel row number. Midparent heterosis did not decrease for most traits as mass selection proceeded, and for juvenile plant height and kernel row number heterosis increased by $>18 \%$.

\section{Discussion}

Mild stratified mass selection for temperate-zone adaptation improved per se performance for six of the 11 traits measured.
However, ear length did not increase in response to mass selection for ear type (Table 2). The phenotypic correlation coefficient for plant height and ear length across the three levels of selection was 0.41 . This relationship may have counteracted the very low selection intensity for ear length as just one component of the complex selection criterion "ear type". Differential drying and shrinkage among ears evaluated during the 10 cycles of mass selection, or during evaluation (over 21 days) in this study, also may have been responsible for the lack of gain in ear length.

Expression of tip blanking undoubtedly is greatly affected by environmental stress. Hansen et al. (1977) reported than environmental variation comprised from $19 \%$ to $65 \%$ of phenotypic variation for tip blanking in a sweet corn diallel. In their study, tip blanking was measured as centimeters from the cob tip back to the last-developed kernels. However, to standardize the data, we chose to express tip blanking as a percentage of total ear length. For cycle $0,31 \%$ to $40 \%$ of estimated phenotypic variation among $\mathrm{S}_{1}$ families was due to environment, and the low selection intensities employed were not effective.

Percentage stalk breakage increased during selection (Table 2). Troyer and Larkins (1985) also found that mass selection for earliness in an adapted field corn $\mathbf{x}$ exotic population resulted in an increase in stalk breakage. They reported that stalk breakage was correlated with earliness in their germplasm. The phenotypic correlation over cyles was -0.24 and -0.32 for percentage stalk breakage vs. heat units to $50 \%$ anthesis and heat units to $50 \%$ silking, respectively.

Pericarp thickness did not change during selection for adaptation (Table 2). Therefore, selection pressure for increased germination in the temperate environment and for kernel type did not affect mean pericarp thickness. This result is consistent with those of Tracy and Juvik (1989) who found no change in pericarp thickness following 10 cycles of mass selection for improved field emergence and seed weight in a shrunken-2 sweet corn population in Illinois.

Pericarp thickness has been reported to have a narrow-sense heritability of $80 \%$ (Helm and Zuber, 1972) and $72 \%$ (Ho et al., 1975) in field corn germplasm. In addition, Ito and Brewbaker (1981) reported a genetic gain of $9.2 \%$ per cycle of mass selection for thin pericarp in the brittle-1 open-pollinated sweet corn cultivar Hawaiian Super-sweet \#9. Since genotypic variability was maintained in Composite $1 \mathrm{R}$ (Table 3), selection for thin pericarp should be productive.

Table 4. Mean values of plant and ear characteristics in testcrosses, their linear regression coefficient (b), lack of fit (LOF), and cycle 10 vs. control contrasts for three cycles of selection, tested in two locations.

\begin{tabular}{|c|c|c|c|c|c|c|c|c|c|c|c|c|c|c|}
\hline \multirow[b]{3}{*}{ Characteristic $^{z}$} & \multicolumn{7}{|c|}{ I453 testcrosses } & \multicolumn{7}{|c|}{ I5125B testcrosses } \\
\hline & \multicolumn{3}{|c|}{ Cycle } & \multirow[b]{2}{*}{$\mathrm{b}$} & \multirow[b]{2}{*}{ LOF } & \multirow[b]{2}{*}{ Control? } & \multirow[b]{2}{*}{ control } & \multicolumn{3}{|c|}{ Cycle } & \multirow[b]{2}{*}{$\mathrm{b}$} & \multirow[b]{2}{*}{ LOF } & \multirow[b]{2}{*}{ Control } & \multirow{2}{*}{$\begin{array}{l}\text { C10 vs. } \\
\text { control }\end{array}$} \\
\hline & $\mathrm{CO}$ & $\mathrm{C} 5$ & $\mathrm{C} 10$ & & & & & $\mathrm{CO}$ & $\mathrm{C5}$ & $\mathrm{C} 10$ & & & & \\
\hline Anthesis (heat units) & 640 & 609 & 598 & $-4.2^{* *}$ & $* *$ & 596 & NS & 628 & 599 & 588 & $-4.0^{* *}$ & $* *$ & 584 & NS \\
\hline Silking (heat units) & 723 & 677 & 661 & $-6.2^{* *}$ & $* *$ & 653 & NS & 702 & 652 & 633 & $-6.8^{*}$ & $* *$ & 624 & NS \\
\hline $\begin{array}{l}\text { Juvenile plant ht } \\
(\mathrm{cm})\end{array}$ & 35.6 & 37.5 & 40.6 & $0.5^{* *}$ & NS & 36.3 & $* *$ & 46.7 & 48.1 & 50.9 & $0.4^{* *}$ & NS & 44.0 & $* *$ \\
\hline Plant ht $(\mathrm{cm})$ & 216 & 210 & 206 & $-1.0 * *$ & NS & 201 & $* *$ & 229 & 220 & 212 & $-1.6^{* *}$ & NS & 202 & $* *$ \\
\hline Ear ht $(\mathrm{cm})$ & 98.5 & 85.7 & 83.1 & $-1.5^{* *}$ & $* *$ & 73.4 & $* *$ & 105 & 91.3 & 87.8 & $-1.8 * *$ & $* *$ & 74.5 & $* *$ \\
\hline Barrenness (\%) & 12.5 & 5.4 & 7.6 & $-0.5 * *$ & $* *$ & 4.4 & NS & 11.4 & 5.1 & 5.1 & $-0.6^{* *}$ & $* *$ & 2.3 & NS \\
\hline Stalk breakage (\%) & 6.7 & 12.9 & 17.9 & $1.1^{* *}$ & NS & 20.6 & NS & 10.1 & 16.3 & 20.9 & $1.1^{* *}$ & NS & 26.4 & $*$ \\
\hline Ear length $(\mathrm{cm})$ & 20.7 & 20.1 & 20.1 & $-0.1 * *$ & $*$ & 19.8 & NS & 21.0 & 20.0 & 19.5 & $-0.2^{* *}$ & NS & 19.5 & NS \\
\hline Tip blanking (\%) & 4.4 & 4.5 & 4.9 & $0.0^{\mathrm{NS}}$ & NS & 4.3 & NS & 6.3 & 5.7 & 6.8 & $0.0^{\mathrm{NS}}$ & $* *$ & 5.7 & $*$ \\
\hline Row number & 15.0 & 16.5 & 16.8 & $0.2 * *$ & $*$ & 15.8 & $* *$ & 16.5 & 18.1 & 18.7 & $0.2^{* *}$ & $* *$ & 17.1 & $* *$ \\
\hline
\end{tabular}

${ }^{2}$ Control was the testcross means of the sweet corn parents of Composite IR (excluding I453 $\times$ I453 and I5125B $\times$ I5125).

NS, *,**Nonsignificant or significant at $P=0.05$ or 0.01 , respectively. 
Table 5. Phenotypic correlation coefficients between $\mathrm{S}_{1}$ families and their testcrosses for three cycles of selection combined over 40 families and two locations.

\begin{tabular}{lcccccc}
\hline \hline & \multicolumn{3}{c}{ S1 vs. I453 } & \multicolumn{3}{c}{ S1 vs. I5125B } \\
\cline { 2 - 7 } & \multicolumn{3}{c}{ Cycle } & \multicolumn{3}{c}{ Cycle } \\
\cline { 2 - 7 } Characteristic & C0 & C5 & C10 & C0 & C5 & C10 \\
\hline Anthesis & 0.69 & 0.81 & 0.75 & 0.65 & 0.80 & 0.80 \\
Silking & 0.57 & 0.68 & 0.72 & 0.57 & 0.67 & 0.72 \\
Juvenile plant ht & 0.48 & 0.39 & 0.24 & 0.45 & 0.50 & 0.52 \\
Plant ht & 0.42 & 0.56 & 0.56 & 0.54 & 0.61 & 0.55 \\
Ear ht & 0.63 & 0.60 & 0.62 & 0.62 & 0.67 & 0.66 \\
Barrenness & 0.30 & $0.00^{\text {NS }}$ & 0.22 & 0.32 & $0.06^{\text {NS }}$ & $0.11^{\text {NS }}$ \\
Stalk breakage & 0.32 & 0.26 & 0.24 & 0.25 & 0.36 & 0.32 \\
Ear length & 0.45 & 0.51 & 0.39 & 0.25 & 0.41 & 0.42 \\
Tip blanking & 0.30 & 0.30 & 0.29 & 0.27 & 0.30 & 0.23 \\
Row number & 0.58 & 0.63 & 0.53 & 0.62 & 0.52 & 0.58 \\
\hline
\end{tabular}

Ns Nonsignificant. All other correlation coefficients are significantly different from 0 at $P=0.01$.

Table 6. Mean percentage midparent heterosis ${ }^{2}$ for three cycles of selection combined over 40 families and two locations.

\begin{tabular}{lrrrrrr}
\hline \hline & \multicolumn{3}{c}{ I453 testcrosses } & \multicolumn{3}{c}{ I5125B testcrosses } \\
\cline { 2 - 7 } & \multicolumn{3}{c}{ Cycle } & \multicolumn{1}{c}{ Cycle } \\
\cline { 2 - 7 } Characteristic & \multicolumn{1}{c}{ C0 5} & C10 & C0 & \multicolumn{1}{c}{ C5 } & C10 \\
\hline Anthesis & -3.9 & -3.6 & -4.4 & -6.6 & -6.0 & -6.9 \\
Silking & -4.6 & -3.7 & -4.7 & -6.6 & -6.5 & -7.9 \\
Juvenile plant ht & 18.2 & 27.3 & 33.3 & $r 60.2$ & 67.8 & 71.5 \\
Plant ht & 14.3 & 16.7 & 15.5 & 20.8 & 21.8 & 18.7 \\
Ear ht & 18.8 & 23.9 & 19.8 & 14.4 & 16.1 & 11.5 \\
Barrenness & -95.5 & -97.9 & -97.1 & -98.9 & -99.5 & -99.5 \\
Stalk breakage & -99.5 & -99.1 & -98.8 & -99.3 & -98.9 & -98.6 \\
Ear length & 16.6 & 14.4 & 16.3 & 44.7 & 40.0 & 38.6 \\
Tip blanking & -11.9 & -9.9 & -12.9 & -39.4 & -44.6 & -36.5 \\
Row number & 1.5 & 2.8 & 3.4 & -0.6 & 1.1 & 3.3 \\
\hline
\end{tabular}

${ }^{\mathrm{z}}$ Heterosis $=100\left(\mathrm{~F}_{1}-\mathrm{MP}\right) / \mathrm{MP}$.

Midparent heterosis would be expected to decrease if Composite $1 \mathrm{R}$ was becoming more genetically similar to the elite testers I453 and I5125B. However, for 13 of 20 cases, average midparent heterosis increased from cycle 0 through cycle 10 of mass selection and for the remaining cases heterosis decreased slightly (Table 6). Therefore, selection in sweet corn $\mathrm{x}$ tropical maize composites for adaptation to temperate regions does not necessarily result in a great loss of midparent heterosis. Moll et al. (1965) found evidence of "an optimum degree of genetic divergence for maximum expression of heterosis in maize". Selection may have eliminated the components of Composite $1 \mathrm{R}$ that are most genetically divergent from the adapted sweet corn testers, thus reducing the likelihood of putative unharmonious gene combinations in later cycles.

Selection within $100 \%$ exotic populations would bypass the possible restrictions of genetic recombination in adapted $\mathrm{x}$ exotic populations, although there would be no germplasm exchange between exotic and adapted gene pools (Hallauer, 1978). The development of $100 \%$ tropical populations for direct use in temperate breeding programs may be difficult for some potentially useful, but highly unadapted, exotics. In these instances, crossing with adapted germplasm remains the logical alternative.

The number of cycles of mass selection necessary to reach a level of adaptation similar to local hybrids and breeding material depends on the germplasm, the selection intensity, and the range of latitude exchange (Hallauer and Miranda, 1981). Once mild selection has adequately adapted the hybrid population, more intense selection could be used (Hallauer and Miranda, 1981). Since the mean and variance for most of the 11 traits in the $S_{1}$ families did not change markedly from cycles 5 through 10 , a more stringent form of selection, such as multiple-environment family selection, may be necessary to advance these traits after cycle 5. The hierarchical open-ended system [HOPE system proposed by Kannenberg (1981)] with its low, intermediate, high, and elite population levels, may prove to be an effective procedure for systematically introgressing tropical maize germplasm into that of temperate sweet corn.

Additional sources of tropical germplasm are likely to have a positive influence on the combining ability of sweet corn inbred families. However, much of the tropical germplasm available to sweet corn breeders will have a negative impact on kernel quality. Kernel quality must be examined further in Composite $1 \mathrm{R}$ by evaluating agronomically superior $\mathrm{S}_{1}$ families for color, texture, flavor, and aroma.

For the sample of tropical parents used in the development of Composite 1R, positive effects on specific combining ability of $S_{1}$ families for early plant vigor, kernel row number, and percentage stalk breakage are evident. However, $\mathrm{S}_{1}$-testcross correlations were not sufficiently high to predict testcross performance from $S_{1}$ performance, although selection based on this prediction would not be detrimental since no correlation coefficients were negative (Table 5).

Four cycles of random mating followed by five cycles of stratified mass selection were effective for adapting a temperate sweet corn $\times$ tropical maize composite to a northern latitude by permitting genetic improvement while maintaining significant genetic variation. Selection decreased plant height, ear height, and percentage barrenness, and increased earliness and kernel row number. Significant genetic variability for 11 plant and ear traits remained after 10 cycles of mass selection and should permit continued improvement, especially if stronger selection pressures are applied. Composite $1 \mathrm{R}$ has the potential to contribute new genetic diversity to and, thus, broaden the genetic base of temperate sweet corn.

\section{Literature Cited}

Compton, W. A., R.F. Mumm, and B. Mathema. 1979. Progress from adaptive mass selection in incompletely adapted maize populations. Crop Sci. 19:531-533.

Davis, D.W. and S.L. Grier. 1978. Resistance of some sweet corn germplasm to second brood European corn borer. Annu. Plant Resistance Insects Nwsl. 4:23-25.

Davis, D. W., C.A. Engelkes, and J.V. Groth. 1990. Erosion of resistance to common leaf rust in exotic-derived maize during selection for other traits. Phytopathology. 80:339-342.

Duvick, D.N. 1984. Genetic diversity of major farm crops on the farm and in reserve. Econ. Bot. 38: 161-178.

Galinat, W.C. 1971. The evolution of sweet corn. Mass. Agr. Expt. Sta. Res. Bul. 591

Goodman, M.M. 1965. Estimates of genetic variance in adapted and exotic populations of maize. Crop Sci. 5:87-90.

Hallauer, A.R. 1978. Potential of exotic germplasm for maize improvement, p. 229-247. In: W.L. Walden (cd.). International maize symposium. McGraw-Hill, New York.

Hallauer, A.R. and J.B. Miranda. 1981. Quantitative genetics in maize breeding. Iowa State Univ. Press, Ames.

Hansen, L. A., J.R. Baggett, and K.E. Rowe. 1977. Quantitative genetic analysis of ten characteristics in sweet corn (Zea mays L.). J. Amer. Soc. Hort. Sci. 102:158-162.

Hanson, W.D. 1959. The breakup of initial linkage blocks under selected mating systems. Genetics 44:857-868. 
Helm, J.L. and M.S. Zuber. 1972. Inheritance of pericarp thickness in Corn Belt maize. Crop Sci. 12:428-430.

Ho, L. C., L.W. Kannenberg, and R.B. Hunter. 1975. Inheritance of pericarp thickness in short season maize inbreds. Can. J. Genet. Cyt. 17:621-629.

Honey, R.N. and M.M. Goodman. 1988. Yield potential of tropical hybrid maize derivatives. Crop Sci. 28:213-218.

Ito, G.M. and J.L. Brewbaker. 1981. Genetic advance through mass selection for tenderness in sweet corn. J. Amer. Soc. Hort. Sci. 106:496-499.

Kannenberg, L.W. 1981. Activation and deployment of genetic resources in a maize breeding program, p. 393-399. In: G.G.E. Seudder and J.L. Reveal (eds.). Evolution today. Proc. 2nd Intl. Congr. of Systematic and Evolutionary Biol. Univ. British Columbia, Vancouver.

Kaukis, K. and D.W. Davis. 1986. Sweet corn breeding, p. 475-519. In: M.J. Bassett (cd.). Breeding vegetable crops. AVI, Westport, Conn.

Kramer, A. B., R.B. Guyer, and L.E. Ide. 1949. Factors affecting the objective and organoleptic evaluation of quality in sweet corn. Proc. Amer. Soc. Hort. Sci. 54:342-356.
Lonnquist, J.H. 1974. Consideration and experiences with recombination of exotic and corn belt maize germplasms. Proc. Annu. Corn and Sorghum Res. Conf. 29:102-117.

Marston, A.R. and C.H. Mahoney. 1932. Progress report on the breeding of sweet corn for corn borer resistance. Proc. Amer. Soc. Hort. Sci. 29:472-476.

Moll, R. H., J.H. Lonnquist, J. Velez Fortuno, and E.C. Johnson. 1965. The relationship of heterosis and genetic divergence in maize. Genetics 52:139-144.

Singleton, W.R. 1948. Hybrid sweet corn. Conn. Agr. Expt. Sta. Bul. 518.

Tracy, W.F. and J.A. Juvik. 1989. Pericarp thickness of ashrunken2 population of maize selected for improved field emergence. Crop Sci. 29:72-74.

Tracy, W.F. and D.H. Schmidt. 1987. Effect of endosperm type on pericarp thickness in sweet corn inbreds. Crop Sci. 27:692-694.

Troyer, A.F. and W.L. Brown. 1972. Selection for early flowering corn. Crop Sci. 12:301-304.

Troyer, A.F. and J.R. Larkins. 1985. Selection for early flowering in corn: 10 late synthetics. Crop Sci. 25:695-697. 